
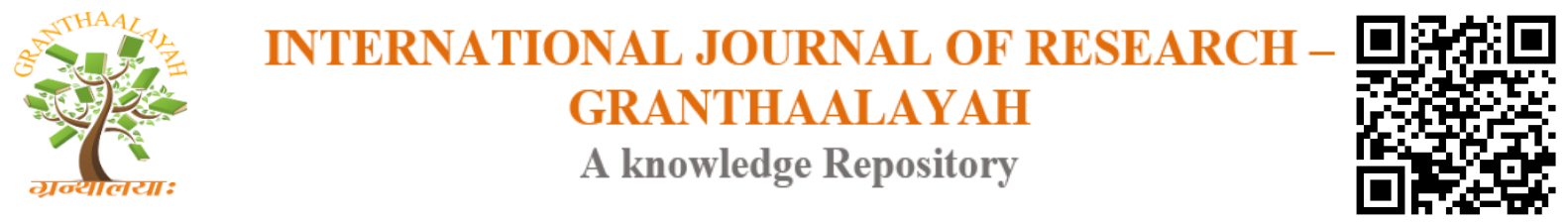

Science

\title{
EVALUATION OF THE ACUTE TOXICITY OF LIANA BARK OF LANDOLPHIA OWARIENSIS P. BEAUV. (APOCYNACEAE)
}

\author{
Dally Laba Ismael *1, Fofana Yaya ${ }^{\mathbf{1}}$, Kablan Ahmont Landry Claude ${ }^{2}$, Lia Arthur José ${ }^{1}$ \\ ${ }^{1}$ Laboratoiry of Galenic Pharmacy, Cosmetology and Legislation, Faculty of Pharmaceutical and \\ Biological Sciences, Félix Houphouët-Boigny University, 06 BP 739 Abidjan 06, Ivory Coast. \\ ${ }^{2}$ Faculty of Biological Sciences, Peleforo Gon Coulibaly University, BP 1328 Korhogo, Ivory \\ Coast
}

\begin{abstract}
The objective of this study was to assess the acute toxicity of the decocted bark of the liana bark of L. owriensis P. Beauv. (Apocynaceae) in the Wistar strain rat. The study of acute toxicity was carried out according to the OECD 423 method. This study was carried out up to a limit dose of $5000 \mathrm{mg} / \mathrm{kg}$ of body weight. After administration of different oral doses, observations on behavior, respiration, skin effects, response of the sensory nervous system or the gastrointestinal effects of animals were made on the 1st, 2nd, 3rd and 14 days (OECD 423). During 14 days of observation, a decoction of the bark of liana from L. owriensis did not show any mortality or lead to obvious toxicity on the mice at the respective doses of 300,2000 and $5000 \mathrm{mg} / \mathrm{kg}$. The decoction is not toxic to rats, even in large doses $(5000 \mathrm{mg} / \mathrm{kg}$ of body weight). Therefore, the vine barks of this plant could be used for effective therapeutic purposes.
\end{abstract}

Keywords: Apocynaceae; Landolphia Owariensis; Acute Toxicity; LD 50.

Cite This Article: Dally Laba Ismael, Fofana Yaya, Kablan Ahmont Landry Claude, and Lia Arthur José. (2020). "EVALUATION OF THE ACUTE TOXICITY OF LIANA BARK OF LANDOLPHIA OWARIENSIS P. BEAUV. (APOCYNACEAE)." International Journal of Research - Granthaalayah, 8(4), 167-172. https://doi.org/10.29121/granthaalayah.v8.i4.2020.22.

\section{Introduction}

Plants are used in medicine, providing many drugs from the earliest times to the present, and as the feedstock for many industrial products as well as a wide range of chemicals [1]. Plant species are important for drug development and pharmacological research, not only when plant constituents are used directly as therapeutic agents $[2,3]$.

In recent years, however, research on medicinal plants has been carried out using a combination of pharmacological studies [4]. These studies are conducted on plants to determine their toxicity and the activities possessed by the species under study. Acute toxicity 


\section{Materials and Methods}

\subsection{Materiel}

\subsubsection{Plant Material}

Landolphia owariensis liana bark was collected in November 2017 in Séguéla (Djibrosso-Kani, northern Côte d'Ivoire). They were identified by Professor Tra Bi Fezan Honora of Nangui Abrogoua University (Côte d'Ivoire).

\subsubsection{Animal Material and Method of Administration}

Eighteen rats (Wistar) weighing between 160 and $202 \mathrm{~g}$ were used in this study. They were purchased and maintained at Nangui Abrogoua University pet store for experimental purposes. The animals were kept under controlled conditions of temperature $(23 \pm 2){ }^{\circ} \mathrm{C}$, humidity $(50 \pm 5)$ $\%$ and 12-hour light-dark cycles. All animals were acclimatized for seven days prior to the study. Animals were randomized into groups (experimental and control) and individually housed in sanitized polypropylene cages containing a sterile paddy wrap as bedding. They had free access to standard pellets as a staple diet and water at will. The animals were accustomed to the laboratory conditions 48 hours prior to the experimental protocol in order to minimize any non-specific stress.

\subsubsection{Apparatus and Other Equipment}

- Retsch GM 300 shredder

- Rotary Evaporator RC600-KnF

- $1 \mathrm{~mL}$ syringes with a 50-12 metal mouse feeding tube for intraesophageal administration.

\subsection{Extraction}

\subsubsection{Procedure}

The preparation of the decocted of L. owariensis was carried out as follows: the powder of the dried liana bark $(20 \mathrm{~g})$ was introduced into a glass jar with a capacity of $350 \mathrm{~mL}$. Then $200 \mathrm{~mL}$ of distilled water was added and hermetically sealed. The closed container containing the mixture was placed in a boiling bath $\left(100{ }^{\circ} \mathrm{C}\right)$ for 30 minutes. The mixture (powder and distilled water) after heating was filtered through Whatmann filter paper No 3 and then evaporated under reduced pressure by a rotary evaporator to yield $485.7 \mathrm{mg}$ of crude aqueous extracts of Landolphia owariensis.

\subsection{Acute Toxicity Assessment Method}

The acute toxicity of L. owariensis decocted was determined in rats using OECD Method 423 [4]. 


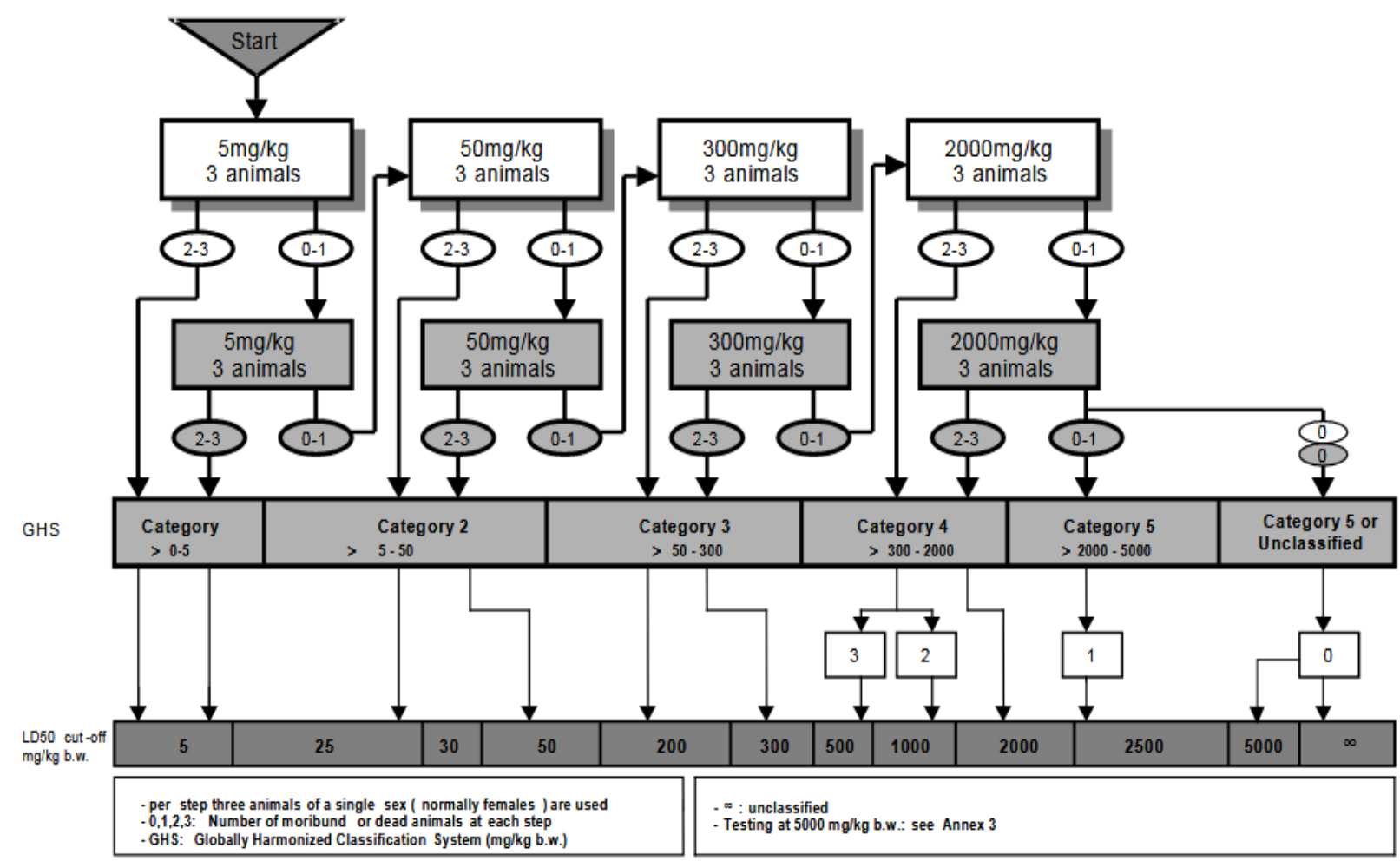

Figure 1: Acute toxicity assessment method for our extract (OECD 423)

Rats fasted for $16 \mathrm{~h}$ were randomly assigned to groups of three rats per group. Graduated doses of the extract $(5,50,300,2000$ and $5000 \mathrm{mg} / \mathrm{kg} \mathrm{bw})$ were administered separately to the rats in each group using a curved steel needle. All rats were then allowed free access to food and water. They were observed for 24 hours to look for signs of acute toxicity. The number of deaths during this period was recorded.

- $\quad 0 \mathrm{mg} / \mathrm{kg}(0 \mathrm{mg} / \mathrm{mL})<$ category $1 \leq 5 \mathrm{mg} / \mathrm{kg}(0.25 \mathrm{mg} / \mathrm{mL})$

- $5 \mathrm{mg} / \mathrm{kg}(0.25 \mathrm{mg} / \mathrm{mL})<$ category $2 \leq 50 \mathrm{mg} / \mathrm{kg}(2.5 \mathrm{mg} / \mathrm{mL})$

- $50 \mathrm{mg} / \mathrm{kg}(2.5 \mathrm{mg} / \mathrm{mL})<$ category $3 \leq 300 \mathrm{mg} / \mathrm{kg}(15 \mathrm{mg} / \mathrm{mL})$

- $300 \mathrm{mg} / \mathrm{kg}(15 \mathrm{mg} / \mathrm{mL})<$ category $4 \leq 2000 \mathrm{mg} / \mathrm{kg}(100 \mathrm{mg} / \mathrm{mL})$

- $\quad-2000 \mathrm{mg} / \mathrm{kg}(100 \mathrm{mg} / \mathrm{mL})<$ category $5 \leq 5000 \mathrm{mg} / \mathrm{kg}(250 \mathrm{mg} / \mathrm{mL})$

\section{Results and discussion}

\subsection{Results}

\subsubsection{Acute Toxicity Test}

For the acute toxicity study, the oral administration to rats of graduated doses $(5,50,300,2000$ and $5000 \mathrm{mg} / \mathrm{kg} \mathrm{bw}$ ) of decoction of L. owariensis did not show any significant change in behavior, respiration, skin effects, the sensory or gastrointestinal nervous system responses during the observation period. No mortality or toxic reaction was recorded in the different groups, 24 hours after administration. A decoction of L. owariensis is safe up to a dose of $5000 \mathrm{mg} / \mathrm{kg}$ of body weight. 


\subsubsection{Weight Development}

All treated animals showed a positive weight change. The evolution of the weight of the animals during the 14 days of the experiment is recorded in Table 1.

Table 1: Change in average animal weight

\begin{tabular}{|c|c|c|c|c|}
\hline $\begin{array}{c}\text { Doses administered } \\
(\mathbf{m g} / \mathbf{~ K g})\end{array}$ & $\begin{array}{c}\text { Average body weight of animals } \mathbf{( g )} \\
\mathbf{J 1 4}\end{array}$ & Variation Test t of Student (5 \%) & & \\
\hline 5 & $160.60 \pm 28$ & $170.20 \pm 25$ & 9.60 & NS \\
\hline 50 & $170.60 \pm 28$ & $180.20 \pm 25$ & 9.60 & NS \\
\hline 300 & $192.15 \pm 25$ & $197.30 \pm 17$ & 5.20 & NS \\
\hline 2000 & $201.60 \pm 30$ & $206.75 \pm 15$ & 5.15 & NS \\
\hline 5000 & $196.20 \pm 13$ & $208.70 \pm 11$ & 12.90 & NS \\
\hline
\end{tabular}

What does NS mean: Not significant ( $\mathrm{p}>0.05$ ); Jo: 1st day of administration of the decoction; D14: 14 days after administration of the decoction.

\subsection{Observations for 24 hours and 14 days}

Table 2: Different observations made in 24 hours and 14 days during the test on the control and the experimental batch

\begin{tabular}{|l|c|c|c|c|}
\hline Observations & \multicolumn{2}{|c|}{ Control lot } & \multicolumn{2}{c|}{ Experimental Lot } \\
\hline & 24 hours & 14 days & 24 hours & 14 days \\
\hline Skin and Fur & Normal & Normal & Normal & Normal \\
\hline Eyes & Normal & Normal & Normal & Normal \\
\hline Mucous membranes & Normal & Normal & Normal & Normal \\
\hline Diarrhea & Absence & Absence & Absence & Absence \\
\hline Salivation & Absence & Absence & Absence & Absence \\
\hline Lethargy & Absence & Absence & Absence & Absence \\
\hline Heartbeats & Normal & Normal & Normal & Normal \\
\hline Aggressiveness & Absence & Absence & Absence & Absence \\
\hline Sleepiness & No & No & yes & No \\
\hline Power supply & yes & yes & yes & yes \\
\hline Mobility & yes & yes & yes & yes \\
\hline Mortality & No & No & No & No \\
\hline
\end{tabular}

During the 14 days following treatment no mortality was observed. 


\section{Discussion}

Table 3: Organ Mass of Treated Rats and Rats Receiving 5000 mg / kg body weight

\begin{tabular}{|l|l|c|c|c|c|}
\hline \multirow{2}{*}{$\begin{array}{l}\text { Group of } \\
\text { animals }\end{array}$} & Treatment and & \multicolumn{4}{|c|}{ Organ weights } \\
\cline { 2 - 5 } Control Rats & Weight in $(\mathrm{g})$ of & $3.79 \pm 0.30$ & $0.42 \pm 0.04$ & $0.33 \pm 0.023$ & $0.34 \pm 0.023$ \\
& untreated & $3.81 \pm 0.32$ & $0.41 \pm 0.02$ & $0.32 \pm 0.025$ & $0.33 \pm 0.026$ \\
& control animals & $3.83 \pm 0.29$ & $0.43 \pm 0.04$ & $0.34 \pm 0.024$ & $0.33 \pm 0.023$ \\
& & & & & \\
\hline Experimental & Weight in $(\mathrm{g})$ of & $3.84 \pm 0.28$ & $0.45 \pm 0.04$ & $0.36 \pm 0.021$ & $0.35 \pm 0.022$ \\
Rats & animals treated & $3.85 \pm 0.27$ & $0.44 \pm 0.03$ & $0.39 \pm 0.020$ & $0.38 \pm 0.019$ \\
& at 5000 mg / kg & $3.84 \pm 0.29$ & $0.42 \pm 0.02$ & $0.38 \pm 0.021$ & $0.39 \pm 0.022$ \\
& body weight & & & & \\
& dose & & & & \\
\hline
\end{tabular}

Landolphia owariensis is an Apocynaceae used in several regions of Africa for its various therapeutic virtues. In this study, we are carrying out in upstream stages of the design of an Improved Traditional Medicine (ATM) for the treatment of haemorrhoidal attacks.

The evaluation of acute toxicity consists in measuring and recording the various adverse effects that appeared after the administration of the tested substance. Indeed, in this work, the animals which received the doses higher than $2000 \mathrm{mg} / \mathrm{Kg}$ did not show changes in behaviour and neither more or less serious signs of intoxication (apathy, drowsiness, difficult movement of the animals during the experiment). No cases of mortality were recorded. At the end of the acute toxicity evaluation test, the $\mathrm{LD}_{50}$ is higher than $5000 \mathrm{mg} / \mathrm{Kg}$ orally. According to the Globally Harmonized System of Classification (GHS), the decoction can be classified as non-toxic [8]. The maximum tolerated dose is $5000 \mathrm{mg} / \mathrm{kg}$ bw / vo. This confirms the idea that the MTD is higher than the doses necessary to have pharmacological effects. Thus, thanks to its DMT of $5000 \mathrm{mg} / \mathrm{kg}$ bw/vol, the decoction offers an appreciable safety margin $[9,10]$. This could reassure us about its possible use as a phytomedicinal agent.

The toxicity study is much more necessary, it will not only identify the range and concentration of the dose that could be used subsequently, but also reveals the possible clinical signs caused by the substances under investigation. In addition, it is also a useful parameter for investigating the therapeutic index of drugs.

\section{Conclusions and Recommendations}

Our work aimed to encourage the use of Landolphia owariensis as a medicinal plant in Côte d'Ivoire in general, and in Seguela in particular. We carried out pre-formulation tests on the decoction of L. owariensis. The results of the acute and subacute toxicity studies showed that a dose of $5000 \mathrm{mg} / \mathrm{kg}$ of body weight of bark of deciduous liana administered by the oral route appeared to be non-toxic. This study confirms that this plant is safe for people who use it in the north of Ivory Coast as a medicine. To our knowledge, this is the first time that this activity has been carried out on the vine bark of this plant. We wish to continue this study, by carrying out the evaluation of antihemorrhoidal activity of the decoction of this plant. 


\section{Acknowledgements}

The authors would like to thank the team of the Department of Clinical Pharmacy and Pharmacology of the Faculty of Pharmacy, University of Felix Houphouët Boigny cocody for providing the materials and chemicals necessary for our study.

\section{References}

[1] African Union. Plan of Action of the Decade of Traditional Medicine (2001 - 2010). Implementation of Decision AHG / DEC.164 (XXXVII) of the Lusaka Conference of Heads of State and Government.

[2] Peter A. G. M., De Smet. An introduction to herbal pharmacoepidemiology. J. Ethnopharm., 38, 1993, $189-195$.

[3] World Health Organization Geneva. General methodological principles for research and evaluation in traditional medicine, 2000, 79.

[4] OECD Guideline for the Testing of Chemicals: Acute Oral Toxicity - Acute Toxicity Class Method, No. 423 (2001).

[5] Leblanc, GA. Acute toxicity. In: A Textbook of Modern Toxicology. 4th ed. John Wiley \& Sons. Inc (Hoboken, New Jersey), 2010.

[6] Fofana, Y., Dally, LI., Kablan, ALC., Lia, AJ. Phytochemical screening and subacute toxicity assessment of decoction of liana bark of Landolphia owariensis P. Beauv. (Apocynaceae) in wistar rats, 8, 2020, 1, 266-276.

[7] Raponda, W., Sillans R. Useful plants from Gabon.Encyclo-Ed. Paul Lechevaler Paris, 1961, 8384.

[8] Olson, H., Betton, G., Robinson, D., Thomas, K., Monro, A., Kolaja, G., Lilly, P., Sanders, J., Sipes, G., Bracken, W., Dorato, M., Van, DK., Smith, P., Berger, B., Heller, A. Concordance of the Toxicity of Pharmaceuticals in Humans and in Animals. Regulatory Toxicology and Pharmacology, 32, 2000, 56 - 67.

[9] El-Hilaly, J., Israili, ZH., Lyoussi, B. Acute and chronic toxicological studies of Ajuga iva in experimental animals. Journal of Ethnopharmacology, 91, 2004, 43-50.

[10] Betti, H.A., Stein C.A., Dallegrave, E., Barth, Wouters A.T., Negrão, W. T., Driemeier, D., Buffon, A., Kuze, M.S. Acute and repeated-doses (28 days) toxicity study of Hypericum polyanthemum Klotzsch ex Reichardt (Guttiferare) in mice.Food and Chemical Toxicology, 50, 2012, 2349-2355.

*Corresponding author.

E-mail address: dismaelfr@yahoo.fr 